EVELINA KRISTANOVA

Uniwersytet Łódzki

Katedra Bibliotekoznawstwa i Informacji Naukowej

\title{
FORMY PROMOCJI KSIAZŻKI W KATOLICKICH CZASOPISMACH SPOŁECZNO-KULTURALNYCH 1. POLOWY XX WIEKU W POlsce
}

Związki zachodzące między książką a prasą mają charakter interdyscyplinarny i należą do istotnych zjawisk kulturalnych. Książkę na łamach prasy promowano już w XVIII wieku. Upowszechnianie reklam książkowych dostarczanych przez wydawców i księgarzy przynosiło redakcjom prasowym spore korzyści finansowe. Dynamizm propagowania książki w prasie szczególnie widoczny był pod koniec XIX i w pierwszej połowie XX wieku. Książka wymagała bowiem szerszego zainteresowania i większej liczby ogłoszeń.

W okresie dwudziestolecia międzywojennego druk tekstów literackich na łamach czasopism przyspieszał profesjonalizację pisarstwa, zachęcał do kupna książki i sprzyjał staraniom redakcji w pozyskiwaniu nowych czytelników. Książka promowana była przede wszystkim na łamach czasopism społeczno-kulturalnych, których powstanie datuje się na lata trzydzieste $\mathrm{XX}$ wieku${ }^{1}$. Znane były one wtedy jako periodyki literackie. Wśród nich osobną grupę tworzyły pisma katolickie.

Artykuł stanowi jedynie kompilację wyników badań prowadzonych przez autorkę w ciągu ostatnich dwunastu lat pod kątem bibliologicznym i podsumowanie dotyczące form promocji książki na łamach czasopism społeczno-kulturalnych o profilu katolickim wydawanych w pierwszej połowie XX wieku. Jego zawartość zatem może nie być zbyt odkrywcza, gdyż niektóre

1 A. Paczkowski, Prasa polska w latach 1918-1939, Warszawa 1980; zob. też: W.P. Szymański, Z dziejów czasopism literackich w dwudziestoleciu międzywojennym, Kraków 1970. 
stwierdzenia znane są z poprzednich opracowań. Zestawienie wybranych czasopism okresu dwudziestolecia międzywojennego z tygodnikami pierwszych lat po wojnie może również budzić zastrzeżenia. Powojenne pisma katolickie działały przecież w jakże odmiennych warunkach historycznych, politycznych i kulturalnych. Należy jednak pamiętać, że w początkowym okresie po zakończeniu działań wojennych wyrażano jeszcze nadzieję na normalne warunki rozwoju kultury i powrót do tradycji II Rzeczypospolitej. To podejście obecne było również w środowiskach katolickich, które próbowały tworzyć odrębny i wolny od ideologii komunistycznej model kultury chrześcijańskiej.

W opracowaniu uwzględniono najbardziej reprezentatywne tytuły prasowe dla lat 1918-1939 oraz wydawane w pierwszych latach po II wojnie światowej. Do nich należały: „Tęcza” (1927-1939), „Kultura” (1936-1939), „Verbum” (1934-1939), „Tygodnik Powszechny” (1945-1953), „Tygodnik Warszawski” (1945-1948) i „Głos Katolicki” (1945-1948). Adresatem wszystkich była inteligencja polska. Postawione pytanie badawcze dotyczyło obecności problematyki książki, jej formy oraz roli, jaką pełniła na ich łamach. Analiza zawartości pism dowiodła, że książka promowana była w różnoraki sposób. Najczęściej stosowaną formą zachęty do lektury była reklama wydawnicza i księgarska. Po niej należy wymienić recenzje książek, informacje o nowościach wydawniczych (przeglądy piśmiennictwa i książki nadesłane do redakcji), notatki o imprezach związanych z książką oraz ogólne rozważania o książkach i czytelnictwie.

\section{Ogólne wprowadzenie do problematyki}

W okresie II Rzeczypospolitej prasa Kościoła katolickiego odgrywała istotną rolę na rynku wydawniczym. Jak pisze Andrzej Paczkowski „Kościół katolicki był instytucją posiadającą najwięcej czasopism i prawdziwą potęgą wydawniczą"2. Ponadto tempo rozwoju ilościowego prasy katolickiej przewyższało tempo ogólnego rozwoju prasy w kraju3 wianych tytułów wynosiły ponad 25 procent całości nakładów polskiego czasopiśmiennictwa ${ }^{4}$. Hierarchia kościelna była bowiem świadoma potęgi oddziaływania ewangelizacyjnego jednego z najważniejszych ówczesnych mediów i kładła tym samym nacisk na działalność prasowo-wydawniczą.

\footnotetext{
2 A. Paczkowski, Prasa polska 1918-1939... s. 293.

3 Tamże.

${ }^{4}$ J. Łojek, J. Myśliński, W. Władyka, Dzieje prasy polskiej, Warszawa 1988, s. 115.
} 
W czasie odradzania się państwa polskiego głos Kościoła uwzględniany był w ważkich sprawach społecznych i kulturalnych. Na łamach pism omawiano zatem najważniejsze kwestie tego okresu i prowadzono polemiki.

Zupełnie odmienne warunki społeczno-polityczne zaistniały w Polsce po II wojnie światowej. Inaczej ukształtowała się też sytuacja prasy katolickiej. Periodyki katolickie wznowione i nowopowstałe nie dorównywały liczbie z okresu dwudziestolecia, gdyż osiągnęły zaledwie od 7 do 11 procent ogólnej produkcji prasowej ${ }^{5}$. Nowa władza komunistyczna o ile $\mathrm{w}$ pierwszych trzech latach stwarzała pozory swobód, o tyle w kolejnych zamykała redakcje czasopism o tym profilu, a ich członków prześladowała i skazywała wyrokami sądowymi. Najbardziej drastycznym przykładem takich działań stał się „Tygodnik Warszawski” (1945-1948), a po nim „Głos Katolicki” (1945-1948). Rok 1953, wychodząc poza połowę XX wieku, stanowił ważną cezurę w historii prasy katolickiej, gdyż wraz z zamknięciem redakcji „Tygodnika Powszechnego” (1945-1953) zlikwidowano niemal wszystkie tytuły tego typu.

W wybranych dwu okresach uwzględniono nowo powstałe czasopisma społeczno-kulturalne, które pomimo niewysokich nakładów, odegrały ważną rolę w kształtowaniu opinii inteligencji polskiej. Pierwsze z uwzględnionych pism dwudziestolecia - bogato ilustrowana „Tęcza” - należało do tzw. pism familijnych. W latach 1927-1931 ukazywało się w formie tygodnika, a w kolejnych (1932-1939) pod redakcją Józefa Kisielewskiego przekształcone zostało w miesięcznik. Wydawcą tego kolorowego pisma była Drukarnia i Księgarnia św. Wojciecha w Poznaniu, a jego nakład wahał się od 8000 do 10000 egzemplarzy ${ }^{6}$. Najbardziej znanym i cenionym w dwudziestoleciu międzywojennym była poznańska „Kultura” (1936-1939) pod redakcją ks. Stanisława Brossa - dyrektora Naczelnego Instytutu Akcji Katolickiej (NIAK). Tytuł przejęto po warszawskim tygodniku redagowanym przez Kazimierza Wierzyńskiego w latach 1931-1932, który „upadł z braku własnej linii programowej" '. Początkowo rozsyłano 15000 egzemplarzy, w drugim roku istnienia nakład periodyku spadł do 5000, natomiast w kolejnych dwóch latach udało się utrzymać 3000 egzemplarzy $^{8}$. Jak pisał ks. Leszek

\footnotetext{
${ }^{5}$ Z. Zieliński, Kościół w Polsce: 1944-2007, Poznań 2009, s. 27.

${ }^{6}$ Szerzej zob.: E. Kristanova, Program społeczny i kulturalny „Tęczy” (1927-1939) na tle prasy katolickiej w II Rzeczypospolitej, Łódź 2006.

7 Cz. Lechicki, Poznańska „Kultura” 1936-1939, „Zeszyty Prasoznawcze” 1985, nr 4, s. 48.

${ }^{8}$ L. Wilczyński, Nowoczesne środki przekazu w działalności Akcji Katolickiej w dwudziestoleciu międzywojennym, s. 3 [online]. [dostęp: 29.06.2013]. Dostępny WWW: www.ak.rumia.pomorskie.pl/materialy/kswilczynski.doc
} 
Wilczyński: „Na łamach tygodnika prezentowano publicystykę, popularyzowano naukę, prozę, krytykę literacką, poezję i powieści. Poruszano także zagadnienia społeczne, polityczne, gospodarcze, filozoficzno-religijne, sztukę, teatr, film, muzykę" . Obok zaprezentowanych tytułów prasowych szczególnym przedsięwzięciem prasowym był wydawany w Warszawie religijny kwartalnik „Verbum” (1934-1939) poświęcony zagadnieniom kultury współczesnej. Pomimo że ukazały się jedynie dwadzieścia dwa numery pisma, odegrało ono znaczącą rolę w upowszechnianiu personalizmu wśród tworzącej się inteligencji katolickiej. Początkowo redaktorem był Konrad Górski (1934 nr 1-2), a po nim ks. Władysław Korniłowicz ${ }^{10}$. Tytuł był wyrazem zainteresowań filozoficznych, kulturalnych i religijnych środowiska skupionego wokół tzw. Kółka ks. Korniłowicza oraz Lasek pod Warszawą, gdzie mieścił się Zakład dla Ociemniałych prowadzony przez Zgromadzenie Sióstr Franciszkanek. Piszący na jego łamach, dążąc do pogłębienia życia duchowego na gruncie filozofii chrześcijańskiej, nawiązywali w swych wypowiedziach do neotomizmu i myśli Jacquesa Maritaina ${ }^{11}$.

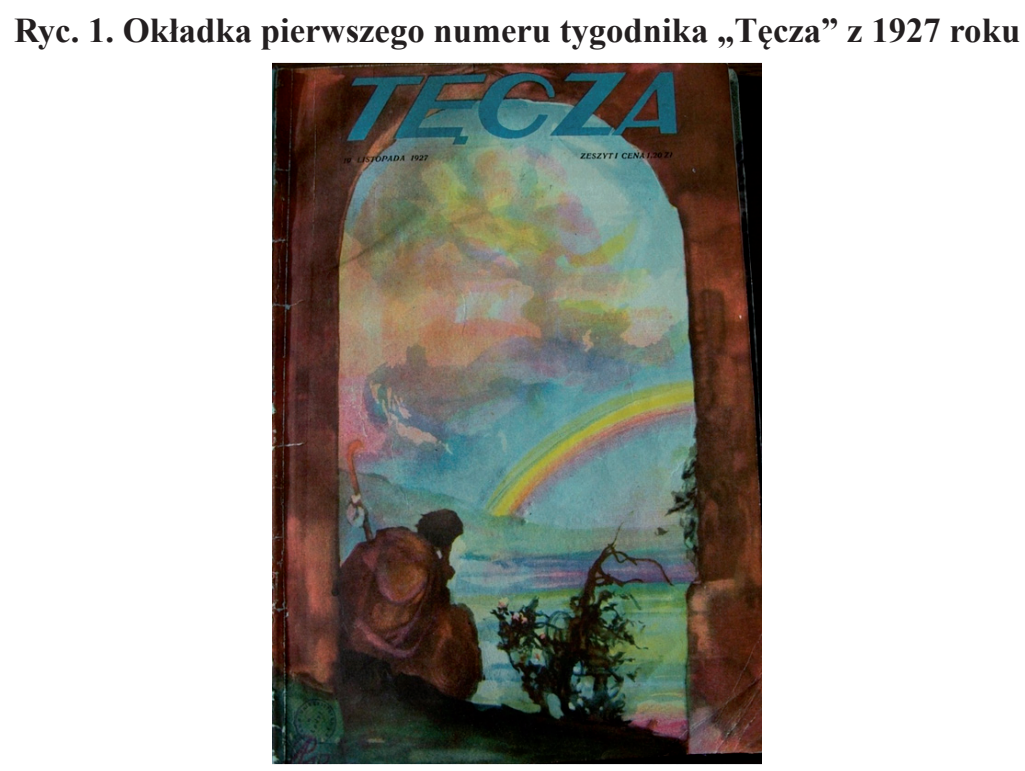

Źródło: Ze zbiorów BUŁ.

9 Tamże, s. 2; zob. też: M. Kunowska-Porębna, Bibliografia zawartości „Kultury” 1936-1939, Lublin 2008.

10 Szerzej zob.: T. Landy, R. Wosiek, Ksiadz Władysław Korniłowicz, Warszawa 1978.

${ }^{11}$ Szerzej zob.: „Verbum” (1934-1939). Pismo i środowisko, oprac. M. Błońska, M. Kunowska-Porębna, S. Sawicki, t. 1-2, Lublin 1976. 
Po II wojnie światowej nie kontynuowano żadnego z wyżej wymienionych pism. Wśród nowych inicjatyw prasowych za najważniejszy uznany został „Tygodnik Powszechny” (1945-1953) pod redakcją ks. Jana Piwowarczyka, a od 1951 roku Jerzego Turowicza. Wydawany z podtytułem „Katolickie pismo społeczno-kulturalne" w Krakowie w nakładzie 50000 egzemplarzy, bogaty był $\mathrm{w}$ różnorodną problematykę ${ }^{12}$ (literatury, historii, sztuki, malarstwa, muzyki, teatru, kina, wychowania ${ }^{13}$, krajoznawstwa). Wokół niego skupiło się środowisko inteligencji świeckiej, które w nowej rzeczywistości politycznej próbowało zachować i propagować wartości chrześcijańskie ${ }^{14}$. W 1953 roku za odmówienie redakcji zamieszczenia nekrologu zmarłego Józefa Stalina pismo zostało zamknięte.

\section{Ryc. 2. Strona tytułowa „Tygodnika Powszechnego” z 1946 roku, nr 16}

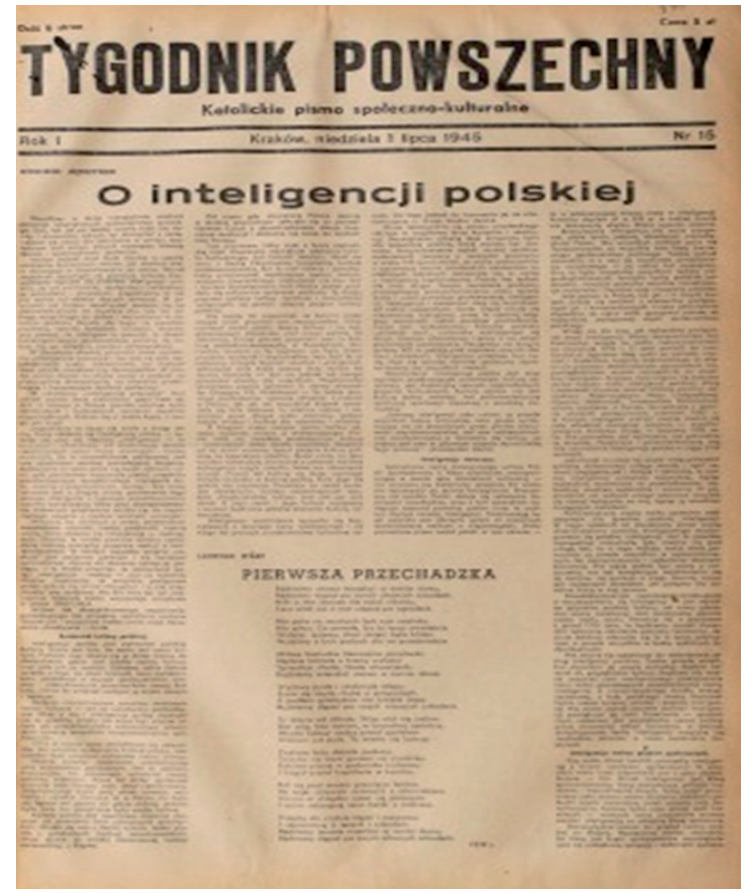

Źródło: Ze zbiorów BUŁ.

12 Szerzej zob.: E. Kristanova, Książka na łamach katolickich czasopism społeczno-kulturalnych $w$ Polsce w latach 1945-1953, Łódź 2012, s. 140-162.

13 Szerzej zob.: M. Strzelecka, Trudne kompromisy. Środowisko „Tygodnika Powszechnego” wobec reform systemu oświaty i wychowania w latach 1945-1989, Torun 2009.

${ }_{14}$ Szerzej zob.: M. Jagiełło, Próba rozmowy. Szkice o katolicyzmie odrodzeniowym i „Tygodniku Powszechnym” 1945-1953, t. 2: „Tygodnik Powszechny” i komunizm 1945-1953, Warszawa 2001. 
Tragiczniejsze losy podzielili współpracownicy i redaktorzy „Tygodnika Warszawskiego" (1945-1948) i „Głosu Katolickiego” (1945-1948), którzy już kilka lat wcześniej zostali uwięzieni. Pierwszy z wymienionych tytułów obok „Tygodnika Powszechnego” uchodził za najbardziej rozpoznawalne i odważne pismo katolickie okresu powojennego. Nakład wahał się od 20000 do 30000 egzemplarzy. Do współtworzących periodyk należeli znani jeszcze w okresie dwudziestolecia międzywojennego duchowni i działacze świeccy. Pierwszym redaktorem został ks. Zygmunt Wądołowski, po nim od 1946 roku do końca istnienia tygodnika funkcję tę pełnił przywódca Chrześcijańskiej Demokracji i kierownik przedwojennej Katolickiej Agencji Prasowej - ks. Zygmunt Kaczyński. W redakcji pracował Jerzy Braun. Wydawcą pisma było Katolickie Towarzystwo Wydawnicze „Rodzina Polska” w Warszawie. Na jego łamach doszło do ostrej polemiki światopoglądowej z marksistami. Oprócz problematyki kulturalnej i społecznej podjęto także religijną, społeczną, gospodarczą ${ }^{15}$. Założycielem i redaktorem ostatniego z prezentowanych pism, poznańskiego „Głosu Katolickiego” (1945-1953) był ks. Roman Mieliński, który skupił wokół niego szerokie grono duchownych i świeckich. Nakład pisma utrzymywał się w granicach 35000 egzemplarzy. Na jego łamach oprócz problematyki religijnej i społecznej chętnie podejmowano tematy rodzinne, wychowawcze, niemieckie, historyczne ${ }^{16}$.

Wszystkie wybrane czasopisma odegrały istotną rolę w kształtowaniu oblicza polskiej inteligencji katolickiej, w tych jakże różnych od siebie okresach historycznych. Na ich łamach publicyści podejmowali polemikę, konfrontując punkt widzenia etyki z przejawami życia w rzeczywistości społeczno-politycznej i kulturalnej dwudziestolecia międzywojennego oraz pierwszych latach po II wojnie światowej. Ważną część materiału prasowego w periodykach zajmowała problematyka książki obecna w różnych formach promocji.

15 Szerzej zob.: E. Kristanova, „Tygodnik Warszawski” (1945-1953) a władza komunistyczna, [w:] Niewygodne dla władzy. Ograniczanie wolności słowa na ziemiach polskich w XIX $i$ XX w., pod red. D. Degen i J. Gzelli, Torun 2010, s. 357-374; R. Stopikowski, Polemiki światopogladowe na łamach „Tygodnika Warszawskiego”, „Dzieje Najnowsze” 1995, nr 4, s. 101-108; tenże, Problematyka gospodarczo-społeczna na łamach „Tygodnika Warszawskiego”, „Życie i Myśl” 1998, nr 4, s. 41-59; J. Wiszniewski, Z historii prasy katolickiej w Polsce: Tygodnik Warszawski 1945-1948, Kraków 1998.

${ }^{16}$ Szerzej zob.: E. Kristanova, Książka na łamach... s. 174-191. 


\section{Ryc. 3. Strona tytułowa „Głosu Katolickiego” z 1946 roku, nr 9}

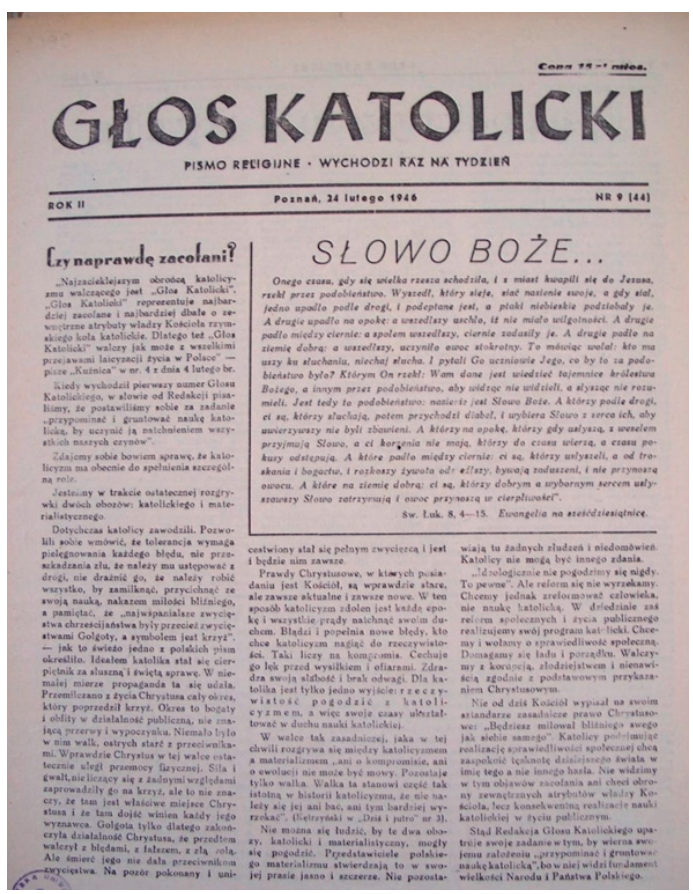

Źródło: Ze zbiorów BUŁ.

\section{Reklama książki}

Na łamach wszystkich zaprezentowanych pism książka obecna była poprzez ogłoszenia wydawnicze i księgarskie. Reklamy przybierały zazwyczaj prostą formę tekstową bez ilustracji i można je było podzielić na małe (reklamowano w nich jedną lub dwie pozycje książkowe), średnie (zawierały kilka tytułów książkowych) i duże (tzw. reklamy zbiorcze od kilkunastu do kilkudziesięciu książek jednego wydawnictwa). Dział reklamowy w niektórych pismach (np. „Tęczy”) obecny był na początku lub końcu numeru, choć nie rezygnowano także z ogłoszeń w zrębie głównym. Anonse dobrane były zgodnie z kręgiem zainteresowań publiczności, do której kierowano tytuły prasowe. Szczególnie ważne miejsce w periodykach zajmowała reklama książki w okresie zbliżających się świąt Bożego Narodzenia lub Wielkanocy. Zwracano również uwagę na uroczystości rodzinne, pierwszą Komunię świętą i tym podobne. Wtedy książki polecano pod nagłówkami zachęcającymi do kupna jej jako prezentu. Oferowano zarówno pozycje dla dorosłych, jak też dla dzieci i młodzieży. 
$\mathrm{Z}$ racji profilu pism przeważały ogłoszenia wydawnictw katolickich: zakonnych, towarzystw i organizacji świeckich.

Proponowano powieści, dzieła religijne, teologiczne, filozoficzne, historyczne, biograficzne, literaturę rozrywkową, podróżniczą i inne. Tematyka była dość różnorodna. Pod względem formy były to monografie, rozprawy, dzieła zbiorowe, tomiki poezji, kazania, albumy, bajki dla dzieci. Niektóre $\mathrm{z}$ pozycji oferowano $\mathrm{w}$ seriach wydawniczych (w okresie dwudziestolecia międzywojennego znaną i lubianą serią była edycja Jasnych Książek czy Biblioteka Książki Chrześcijańskiej) ${ }^{17}$. Książki dostępne były nie tylko w księgarniach, ale jednocześnie w sprzedaży wysyłkowej, zazwyczaj tańszej dla stałych prenumeratorów periodyków.

Redakcja „Tęczy” zamieszczała jedynie reklamy książek swojego wydawcy czyli Drukarni i Księgarni św. Wojciecha cieszącej się bogatym asortymentem książkowym. W „Kulturze” najczęściej ogłaszało się wydawnictwo NIAK, wspomniana wyżej Drukarnia i Księgarnia św. Wojciecha, Wydawnictwo Kultury i Wydawnictwo Księży Jezuitów. Sporadycznie zaś pojawiały się propozycje nowości świeckich wydawców, jak M. Arcta, Gebethnera i Wolffa, Z. Gustowskiego i M. Wojciechowskiego czy Wydawnictwa Polskiego R. Wegnera. Redakcja proponowała swoim czytelnikom m.in. książkę Jacquesa Maritaina Religia i kultura oraz zakonnika Jacka Woronieckiego U podstaw kultury katolickiej. W obu pismach dwudziestolecia proponowano najczęściej powieści rodzimych autorów: Krzyżowcy Zofii Kossak-Szczuckiej, Wyrabany chodnik Gustawa Morcinka, Tęcza nad sercem Jana Wiktora, Bractwo Białego Lamparta Jerzego Marlicza (pseudonim Heleny Borowikowej) czy Ziemia gromadzi prochy Józefa Kisielewskiego. Ostatnią z wymienionych pozycji, wydaną przez Księgarnię i Drukarnię św. Wojciecha, zalecano też w ramach subskrypcji ${ }^{18}$. Na łamach „Kultury” systematycznie reklamowaną powieścią zagraniczną była książka Jezuici, burżuje, bolszewicy Eryka von Kuehnelt-Leddihna. Z życiorysów zaproponowano pozycję Adolfa Nowaczyńskiego Najpiękniejszy człowiek mego pokolenia. Brat Albert ${ }^{19}$. Zwrócono też uwagę na okolicznościowy album zatytułowany Pius $X I^{20}$. Redakcja „Tęczy” pod nagłówkiem „Studia i szkice” reklamowała m.in. Teologię ks. A. Żychlińskiego oraz My, nowe pokolenie Jędrzeja Gierty-

\footnotetext{
${ }_{17}$ Szerzej o repertuarze książki religijnej w dwudziestoleciu międzywojennym pisał P. Nowak, Poznań jako ośrodek wydawniczy w dwudziestoleciu 1919-1939, Poznań 1997 (rozdział VI pt. Literatura religijno-moralna).

18 „Kultura” 1939, nr 25, s. 5.

19 „Kultura” 1937, nr 51-52, s. 14.

20 „Kultura” 1939, nr 11, s. 3.
} 
cha. Z literatury podróżniczej zalecano Kamień $i$ woda Zofii Starowieyskiej-Morstinowej ${ }^{21}$.

Na łamach obu pism oferta ogłoszeniowa dotyczyła różnych grup wiekowych. Obecna zatem była nie tylko książka dla dorosłego czytelnika. Oferta dla młodzieży objęła np. pozycje podróżniczo-przygodowe Jamesa Oliviera Curwooda: Powieści egzotyczne, Włóczęgi pótnocy, Najdziksze serca, Szara wilczyca czy „powieść dla panienek” zatytułowaną Królewna Marii Reuttówny. W powojennym „Tygodniku Powszechnym” najczęściej ogłaszały się: Instytut Wydawniczy „Pax”, Wydawnictwo Mariackie, Wydawnictwo Seminarium Zagranicznego, Wydawnictwo Towarzystwa Przyjaciół KUL, Wydawnictwo Instytutu Zachodniego, Wydawnictwo św. Krzyża i Wydawnictwo Księży Jezuitów. Stali czytelnicy często natrafiali na anonse znanych powieści zagranicznych: Georgesa Bernanosa Pod słońcem szatana i Zakłama$n i e^{22}$, Daniela-Ropsa Nędza i my $y^{23}$ czy Grahama Greene’a Broń na sprzedaż $\dot{z}^{24}$. Z polskich zachęcano do kupna wielotomowej powieści Bolesław Chrobry Antoniego Gołubiewa ${ }^{25}$ oraz powieści Jana Dobraczyńskiego: Klucz mądrości, Listy Nikodema i Największa miłość. Nieustannie powtarzano ofertę Nowego Testamentu w tłumaczeniu ks. Eugeniusza Dąbrowskiego ${ }^{26}$. Młodszym odbiorcom proponowano ilustrowany Mszalik dla dziatwy i młodzieży ks. Stanisława Bielawskiego ${ }^{27}$.

Redakcja „Tygodnika Warszawskiego” drukowała przeważnie reklamy nowości książkowych Katolickiego Towarzystwa Wydawniczego „Rodzina Polska”. Wśród nich znalazł się pamiętnik o historycznym znaczeniu Ludwika Christiansa Piekło XX wieku ${ }^{28}$. Kapłanom zaoferowano natomiast Kazania o Niepokalanym Sercu Marii ${ }^{29}$. Z powieści można było zapoznać się z ogłoszeniem zbeletryzowanego życia św. Piotra pt. Szymon - syn Jony Juliusza Kędziory ${ }^{30}$.

${ }^{21}$ „Kultura” 1937, nr 29, s. 8. Szerzej zob.: E. Kristanova, Reklama książi na łamach poznańskiej „Kultury” (1936-1939), „Acta Universitatis Lodziensis. Folia Librorum” 2001, nr 10, s. 107118.

22 „Tygodnik Powszechny” [dalej „TP”] 1952, nr 42, s. 9.

23 „TP” 1946, nr 26, s. 8.

24 „TP” 1951, nr 21, s. 3.

25 „TP” 1952, nr 36, s. 8.

26 „TP” 1950, nr 6, s. 11.

27 „TP” 1946, nr 47, s. 6.

28 „Tygodnik Warszawski” [dalej „TW”] 1946, nr 42, s. 8.

29 „TW” 1946, nr 27, s. 8.

30 „TW” 1948, nr 30, s. 8. Szerzej zob.: E. Kristanova, Reklama ksiązki na łamach „Tygodnika Warszawskiego" (1945-1948) [w:] Od książki dawnej do biblioteki wirtualnej, pod red. D. Degen i M. Fedorowicz, Toruń 2009, s. 245-263. 
Najmniej reklam w porównaniu do poprzednich pism, wydawanych po II wojnie światowej, ukazało się na łamach „Głosu Katolickiego”. Tu reklamowano powieść zatytułowaną Wybrańcy gwiazd Jana Dobraczyńskiego ${ }^{31}$, nową edycję Ewangelii i Dziejów apostolskich w przekładzie ks. Feliksa Gryglewicza $^{32}$. Odpowiednim podarkiem gwiazdkowym, w opinii ogłoszeniodawcy, miała być historyczna książka Marii i Zygmunta Wojciechowskich Polska Piastów. Polska Jagiellonów ${ }^{33}$.

W ramach serii Jasnych książek Księgarni św. Wojciecha, cieszącej się dużym zainteresowaniem w latach 1936-1939, a wznowionej po II wojnie światowej, polecono Konfesjonał Władysława Jana Grabskiego, Przedziwny wódz Zofii Zawiszanki, Pieśn o Bernadecie Franciszka Werfla, Listy starego diabła do młodego Clive'a Staplesa Lewisa ${ }^{34}$.

Oferta w poszczególnych pismach raczej się nie powtarzała. Jedynie niektóre tytuły należące do tzw. powieści katolickiej i dzieła Maritaina były reklamowane niemal we wszystkich tytułach prasowych. Niektóre z nowości wydawniczych najpierw reklamowano a następnie recenzowano.

\section{Recenzje książek}

W grupie wybranych katolickich czasopism społeczno-kulturalnych wydawanych w pierwszej połowie XX wieku częstą formą promocji nowości wydawniczych były recenzje. Pisali je zazwyczaj znani publicyści katoliccy tacy jak: Artur Górski, Alfred Jesionowski, Józef Kisielewski, Stefan Kisielewski, Hanna Malewska, Maria Morstin-Górska, Aleksander Rogalski czy Zofia Starowieyska-Morstinowa. Publikowano je zarówno w specjalnie przeznaczonych do tego działach, jak też przy okazji podejmowania różnorodnej problematyki. W „Tęczy” opinie pojawiały się m.in. pod nagłówkiem Co czytać?, Książka miesiąca czy Przeglą wydawniczy. Na łamach „Kultury” zaś w Kronice kulturalnej, Półce z książkami oraz w rubryce Wśród książek.

Na łamach pism zazwyczaj skupiano się na propagowaniu „dobrej książki”, czyli takiej, która wyszła spod pióra pisarza uważanego za katolickiego lub w swojej treści zgodna była $\mathrm{z}$ wartościami i etyką katolicką. Dobre opinie miały zatem zachęcić do przeczytania czy nabycia danej pozycji. Zdecydowanie rzadziej w ocenach przestrzegano przed niewłaściwą lekturą.

\footnotetext{
31 „Głos Katolicki” [dalej „GK”] 1948, nr 24, s. 214.

32 „GK” 1947, nr 40, s. 334.

33 „GK” 1946, nr 51, s. 412.

34 Jasne Książki. Katolicki Klub Literacki, „GK” 1948 nr 24, s. 210; „TP” 1948, nr 24, s. 10.
} 
Liczbę książek omówionych w czasopismach okresu II Rzeczypospolitej przedstawia poniższa tabela.

Tabela 1. Dane liczbowe o zrecenzowanych książkach i recenzjach w wybranych czasopismach dwudziestolecia międzywojennego

\begin{tabular}{|c|c|c|c|c|}
\hline Lp. & Tytuł czasopisma & $\begin{array}{c}\text { Lata } \\
\text { ukazywania się }\end{array}$ & $\begin{array}{c}\text { Liczba } \\
\text { zrecenzowanych } \\
\text { książek }\end{array}$ & $\begin{array}{c}\text { Recenzje } \\
\text { w przeliczeniu } \\
\text { na jeden rok }\end{array}$ \\
\hline 1 & „Kultura” & $1936-1939$ & 914 & 233 \\
\hline 2 & „Tęcza” & $1927-1939$ & 312 & 25 \\
\hline 3 & „Verbum” & $1934-1939$ & 39 & 7 \\
\hline
\end{tabular}

Źródło: Opracowanie własne ${ }^{35}$.

Tabela 2. Dane liczbowe o zrecenzowanych książkach i recenzjach w wybranych czasopismach wydawanych w latach 1945-1953

\begin{tabular}{|c|c|c|c|c|}
\hline Lp. & Tytuł tygodnika & $\begin{array}{c}\text { Lata } \\
\text { ukazywania się }\end{array}$ & $\begin{array}{c}\text { Liczba } \\
\text { zrecenzowanych } \\
\text { książek }\end{array}$ & $\begin{array}{c}\text { Recenzje } \\
\text { w przeliczeniu } \\
\text { na jeden rok }\end{array}$ \\
\hline 1 & „Tygodnik Powszechny” & $1945-1953$ & 618 & 71 \\
\hline 2 & „Tygodnik Warszawski” & $1945-1948$ & 224 & 56 \\
\hline 3 & „Głos Katolicki” & $1945-1948$ & 59 & 14 \\
\hline
\end{tabular}

Źródło: Opracowanie własne.

Z powyższych obliczeń wynika, że pomimo krótkiego okresu czterech lat istnienia tygodnika, najwięcej książek zrecenzowano na łamach poznańskiej „Kultury”, gdyż aż 914. Na drugim miejscu uplasowała się „Tęcza”, w której redakcja zamieściła łącznie 312 omówień. Jako trzeci tytuł prasowy należy wymienić „Verbum” - 39 opinii o książkach. Zdecydowanie więcej opinii, gdyż 260, ukazało się w tygodniku „Tęcza” niż w późniejszym miesięczniku - 52 recenzje. Najwięcej z nich napisali: Jerzy Drobnik, Józef Kisielewski, Edward Kozikowski. W „Kulturze” najczęściej

${ }^{35}$ Niektóre obliczenia wykonano z autopsji, inne na podstawie bibliografii: Bibliografia zawartości literackiej „Tęczy” [w:] B. Żynda, Bibliografia wydawnictw Księgarni św. Wojciecha 18951969, Poznań 1970; M. Kunowska-Porębna, Bibliografia zawartości „Kultury”...; M. Błońska, M. Kunowska-Porębna, S. Sawicki, Bibliografia zawartości „Verbum” (1934-1939) [w:] „Verbum” (1934-1939). Pismo i środowisko... s. 137-270. 
o książkach wypowiadali się: Stanisław Helsztyński, Alfred Jesionowski, Zofia Roszkówna i Henryk Weryński. Redakcja „Verbum” opinie o nowościach powierzała natomiast Teresie Landy, Zofii Starowieyskiej-Morstinowej i Rafałowi Blüthowi.

Najwięcej recenzji wśród badanych periodyków powojennych ukazało się w „Tygodniku Powszechnym” (aż 618); zdecydowaną większość z nich napisał ks. Jan Piwowarczyk (42). Najciekawsze i najbardziej żartobliwe opinie wychodziły spod pióra Stefana Kisielewskiego, natomiast znana jeszcze w okresie dwudziestolecia międzywojennego recenzentka Zofia Starowieyska-Morstinowa utrzymywała nadal pogłębione spojrzenie na wymowę każdej książki. Dzieła historyczne omawiał zazwyczaj Paweł Jasienica. W warszawskim organie prasowym (łącznie 224 opinie) recenzentami byli przeważnie Antoni Madej, Jerzy Braun, Jan Archita, Halina Kamieniecka i Zuzanna Rabska. Redaktor „Głosu Katolickiego” oceny nowości przeznaczał zaś Jerzemu Stawskiemu i Aleksandrowi Rogalskiemu.

Chętnie recenzowano książki znanych autorów zagranicznych. Niektóre z nich stanowiły klasykę w zakresie literatury chrześcijańskiej i odnosiły się do dzieł Ojców Kościoła. W większości wybranych tytułów prasowych recenzowano nowe edycje Wyznań św. Augustyna ${ }^{36}$ czy wydanie jego $M y$ $s l^{37}$. W ramach wznowionej po II wojnie światowej poznańskiej serii Pism Ojców Kościoła zauważono Księgę reguły pasterskiej św. Grzegorza Wielkiego $^{38}$. W kręgu zainteresowań publicystów pozostawały także dzieła filozofów, myślicieli, teologów i pisarzy. Na łamach „Kultury” i „Verbum” często omawiano książki znanego współczesnego filozofa Jacquesa Maritaina ${ }^{39}$. W kwartalniku recenzję sprawozdawczą o dwóch znanych jego dziełach Religii i kulturze (Paryż 1930) oraz O porzadku doczesnym i o wolności (Paryż 1933) napisała siostra Teresa Landy ${ }^{40}$.

Osobne miejsce zajęły omówienia kolejnych wydań Pisma świętego. Redakcje „Głosu Katolickiego” i krakowskiego „Tygodnika Powszechnego” wysoko oceniły powojenne wydania Nowego Testamentu w przekładzie

\footnotetext{
36 J. S. Demkow, Wyznania, „Tęcza” 1929, nr 33, s. 4.

37 M. Pachucki, Połów pereł augustiańskich, „Tęcza” 1930, nr 35, s. 2.

38 J. Ujda, Papież Grzegorz Wielki, „GK” 1948, nr 38, s. 322.

39 Np. K. Kowalski, Maritain o pięknie, „Kultura” 1936 nr 11 [rec. książki J. Maritaina, Sztuka i mądrość, tłum. K. i K. Górski, Poznań 1936]; W. Malewski, „Kultura” 1939, nr 31, s. 2 [rec. książki J. Maritaina, Trzej reformatorzy, tłum. K. Michalski, Warszawa 1939]; J. Siwecki, O pełnym humanizmie, „Verbum 1936, nr 3, s. 571-591 [rec. książki J. Maritaina, Humanisme intégral, Paryż 1936].

40 T. Landy, Recenzje, sprawozdania, omówienia, przeglądy, „Verbum” 1934, nr 2, s. 227-244.
} 
ks. Eugeniusza Dąbrowskiego ${ }^{41}$. Pochwalono też edycję Ewangelii i Dziejów Apostolskich w tłumaczeniu ks. Feliksa Gryglewicza ${ }^{42}$.

Szczególne miejsce w recenzjach na łamach katolickich czasopism społeczno-kulturalnych zajmowały opinie o powieściach pisarzy katolickich: Georgesa Bernanosa, Grahama Greene'a, Daniela-Ropsa, Françoisa Mauriaca. Najgłośniejszą książkę pierwszego z nich zatytułowaną Pod słońcem szatana zrecenzowano na łamach „Tygodnika Powszechnego" ${ }^{4}$. Przemianę duchową bohatera powieści Dusza w mroku (Warszawa 1933) Daniela-Ropsa w okresie utraty wiary analizowała na łamach „Verbum” siostra Teresa Landy ${ }^{44}$. Tegoż pisarza Zwycięstwo nad śmiercią i powieść Gertrudy von le Fort Chusta Weroniki zrecenzowano w „Tęczy”45. W piśmie familijnym zauważono też Koniec nocy i Życie Jezusa F. Mauriaca ${ }^{46}$ oraz powieści Knuta Hamsuna Wiktoria, Pan, Marzyciel i Włóczęgi ${ }^{47}$. Najwięcej kontrowersji w opinii publicystów „Tygodnika Powszechnego” wzbudziła powieść Grahama Greene’a Sedno sprawy wydana w polskim przekładzie w 1950 roku. Jedni z recenzentów chwalili ją za głęboki sens, inni zaś zapytywali, czy w ogóle zasługuje na miano powieści katolickiej ${ }^{48}$.

Wyrażano też opinie o książkach Bruno Schulza ${ }^{49}$, André Gide'a ${ }^{50}$, Josepha Conrada ${ }^{51}$, Ericha Marii Remarque'a ${ }^{52}$, Antoine de Saint-Exupéry'ego $^{53}$. Na łamach „Tęczy” Andrzej Tretiak zwrócił uwagę na życie Conrada

${ }^{41}$ K. Madaliński, Niewykorzystane księgi, „GK” 1947, nr 50, s. 407; J. T. Milik, Nowy Testament po polsku, „TP” 1950, nr 30, s. 4.

${ }^{42}$ J. Wierusz-Kowalski, Ewangelie z greckiego..., „TP” 1948, nr 28, s. 11.

${ }^{43}$ Z. Starowieyska-Morstinowa, $W$ walce $z$ szatanem, „TP” 1949, nr 35, s. 7-8.

${ }^{44}$ T. Landy, Recenzje..., „Verbum” 1934, nr 1, s. 110-116.

${ }^{45}$ H. Roma, Zwycięstwo nad śmiercią, „Tęcza” 1935, nr 1, s. 54-55; K. Kuliczkowska, Chusta Weroniki, „Tęcza” 1938, nr 7, s. 37-40.

${ }^{46}$ H. Roma, Nowa powieść Mauriac’a, „Tęcza” 1935, nr 3, s. 54-55; M. Milatycka, „Życie Jezusa” - Fr. Mauriac'a, „Tęcza” 1937, nr 5, s. 29-32.

47 J. Kisielewski, Wiktoria, Pan, Marzyciel, „Tęcza” 1931, nr 4, s. 17; „Tęcza” 1930, nr 11, s. 4.

${ }_{48}$ M. Morstin-Górska, Sensacja i mistyka, „TP” 1948, nr 52/53, s. 5; Z. Starowieyska-Morstinowa, Grzech zdemaskowany, „TP” 1950, nr 31, s. 3; Z. Kubiak, Poszukiwanie prawdy o człowieku, „TP” 1950, nr 32, s. 3; A. Iwaszkiewiczowa, Jeszcze o „Sednie sprawy”, „TP” 1951, nr 49, s. 6.

${ }^{49}$ M. Chmielowiec, Zdarzenia bezdomne, „Kultura” 1938, nr 13, s. 5 [rec. książki B. Schulza, Sanatorium pod klepsydra, Warszawa 1937].

${ }_{50}$ T. Baykowski, Z powodu nowej książki A. Gide’a, „Verbum” 1937, nr 1, s. 210-216 [rec. książki A. Gide’a Retour de l'U.R.S.S., Paryż 1936].

${ }^{51}$ K. Górski, „Lord Jim” Conrada, „Verbum” 1934, nr 1, s. 98-107 [rec. książki J. Conrada, Lord Jim, Warszawa 1933].

52 Z. Zawiszaka, Na zachodzie nic nowego, „Tęcza” 1930, nr 1, s. 3 [rec. książki E. M. Remarque’a, Na Zachodzie bez zmian, 1929]; J. M. Święcicki, E. M. Remarque - epigon biologizmu, „TP” 1949, nr 2, s. 3-4 [rec. książki E. M. Remarque’a, Łuk triumfalny, 1945].

${ }^{53}$ T. Landy, „Verbum” 1934, nr 3, s. 382-389. 
w świetle jego korespondencji ${ }^{54}$, natomiast Edward Kozikowski omówił jego Pisma zbiorowe ${ }^{55}$.

Nie zabrakło również recenzji powieści rodzimych autorów. Na łamach większości pism chętnie omawiano twórczość Zofii Kossak-Szczuckiej. Wśród ocenionych powieści znalazły się: Legnickie pole ${ }^{56}$, Król trędowaty ${ }^{57}, K r z y z \dot{z} o w c y^{58}$, Szaleńcy Boży $y^{59}$ i Złota wolnośćc ${ }^{60}$. Często recenzowano także utwory Gustawa Morcinka. Alfred Jesionowski napisał recenzję Gołębi na dachu oraz Inżyniera Szerudy ${ }^{61}$. Przy okazji drugiego wydania nowel zatytułowanych Serca nad tama Janina Mąkolska-Tokarska na łamach "Kultury” zapytywała, w jaki sposób „czytać Morcinka” ${ }^{2}$. Dowodząc we wstępie do artykułu, że jego książki są trudne w odbiorze, pisała: „Dla tych wszystkich, którzy się wstydzą, że jednak ludzie są dobrzy, autor Wyrąbanego chodnika jest tak niedosiężnym jak kodeks Hammurabiego w oryginale dla tych, co nie znają pisma klinowego, jak czytanie dla analfabety, jak kuracja wegetariańska dla ludożercy"63. Józef Kisielewski spośród licznych opinii w „Tęczy” wyraził swój pogląd m.in. o następujących powieściach: Dziewczęta $z$ Nowolipek Poli Gojawiczyńskiej, Ośmiornica Jerzego Marlicza, Trzecia siostra Wandy Miłaszewskiej, Czerwone maki Stanisława Szpotańskiego i Granica Zofii Nałkowskiej ${ }^{64}$. W tym samym periodyku kilkakrotnie wyrażono też opinię o powieści Zolojka Jerzego Bandrowskiego ${ }^{65}$. Zrecenzowano biograficzną powieść Ferdynanda Ossendowskiego Lenin ${ }^{66}$. Niekiedy odbiorców pism zachę-

\footnotetext{
${ }^{54}$ A. Tretiak, Życie i listy Josepha Conrada, „Tęcza” 1928, nr 9-10, s. 3-4.

${ }^{55}$ E. Kozikowski, Pisma zbiorowe, „Tęcza” 1929, nr 28, s. 14.

${ }_{56}$ M. Arend, Walterskotyzm Kossak-Szczuckiej, „Tęcza” 1931, nr 2, s. 4.

57 J. Kisielewski, Przeglad wydawniczy, „Tęcza” 1937, nr 3, s. 79.

${ }^{58}$ J. Birkenmajer, Krzyż je oczyścił..., „Kultura” 1936, nr 16, s. 1-2 [rec. książki Z. Kossak-Szczuckiej, Krzyżowcy, t. 1-4, Poznań 1935]; J. Kisielewski, Przegląd wydawniczy, „Tęcza” 1936, nr 2, s. 61-62; M. Morstin-Górska, „Verbum” 1936, nr 3, s. 554-558.

59 T. Silnicki, Szaleńcy Boży, „Tęcza” 1929, nr 30, s. 2-3.

${ }^{60}$ W. Lutosławski, Złota wolność, „Tęcza” 1929, nr 3, s. 3.

${ }^{61}$ A. Jesionowski, Bodajeś cudze dzieci uczył..., „Kultura” 1936, nr 30, s. 7; tenże, Na manowcach duszy, „Kultura” 1937, nr 6, s. 5.

62 J. Mąkolska-Tokarska, Jak czytać Morcinka?, „Kultura” 1936, nr 5, s. 5.

63 Tamże.

${ }^{64}$ J. Kisielewski, Przegląd wydawniczy, „Tęcza” 1934, nr 1, s. 75; tenże, Miłość i rewolucja, „Tęcza” 1935, nr 8, s. 65-66; tenże, Przegląd wydawniczy, „Tęcza” 1935, nr 11, s. 65-66; tenże, Przegląd wydawniczy, „Tęcza” 1936, nr 7, s. 67.

${ }^{65}$ R. Bergel, Rybacy Kaszubi w powieści polskiej, „Tęcza” 1929, nr 31, s. 13-14; Scriptor, Na nowej drodze, „Tęcza” 1928, nr 32, s. 2-3.

${ }^{66}$ M. Wojciechowska, Lenin, „Tęcza” 1930, nr 15, s. 11.
} 
cano do sięgnięcia po powieści o tematyce morskiej ${ }^{67}$, sensacyjnej ${ }^{68} \mathrm{czy}$ fantastycznej ${ }^{69}$.

Uwagę publicystów przyciągały również niektóre tomiki poezji. Na łamach „Tęczy” Emil Zegadłowicz wyraził pochlebną opinię o Uchu igielnym Leopolda Staffa ${ }^{70}$, Józef Kisielewski dobrze wypowiedział się o Słowiku litewskim Kazimiery Iłłakowiczówny ${ }^{71}$, a Jerzy Koller na temat Przed noca Jadwigi Popowskiej ${ }^{72}$. Zygmunt Serafinowicz na kartach „Verbum” skrytykował natomiast przy okazji ukazania się wspomnianego tomiku Słowik litewski wiersze polityczne i pisane na „zamówienie społeczne”, dokonał też pobieżnej analizy poezji Wojciecha Bąka na podstawie jego Brzemienia niebieskiego ${ }^{73}$. Na łamach „Kultury” Jarosław Janowski zwrócił natomiast uwagę czytelników na tomik zatytułowany Śpiewna samotność W. Bąka ${ }^{74}$. Edmund Misiołek ocenił z kolei w kwartalniku „Verbum” wiersze Czesława Miłosza $\mathrm{z}$ racji ukazania się $\mathrm{w}$ Wilnie Trzech $z \mathrm{im}^{75}$.

W zawartości czasopism społeczno-kulturalnych recenzowano też dzieła teologiczne, książki historyczne, krajoznawcze, wspomnienia, biografie, hagiografie, korespondencje, słowniki, bibliografie, albumy i inne. Przykładowo w „Kulturze” zabrano głos na temat Słownika pseudonimów i kryptonimów pisarzy polskich oraz Polski dotyczących Adama Bara (Kraków 1936) ${ }^{76}$, wypowiedziano się również o 27. tomie Bibliografii polskiej Karola Estreichera $^{77}$. Z dziedziny literatury politycznej zrecenzowano książkę Romana Dmowskiego Świat powojenny i Polska ${ }^{78}$. Zauważono jednocześnie korespondencje Elizy Orzeszkowej Listy (Warszawa 1937) ${ }^{79}$. Sylwetkę ks. Edwarda Szwejnica, akcentując zagadnienia religijne i duszpasterskie, recenzentka „Verbum” nakreśliła na podstawie wspomnień zatytułowanych

${ }^{67}$ Np. A. Jesionowski, „Kultura” 1936 nr 17 s. 4 [rec. książki M. Jarosławskiego, Zew morza. Powieść morska, Warszawa 1936]

${ }^{68}$ L. [krypt.], Polska powieść sensacyjna, „Tęcza” 1929, nr 39, s. 15.

${ }^{69}$ B. Ostromęcki, Zmowa demiurgów, „TW” 1948, nr 4, s. 7.

${ }^{70}$ E. Zegadłowicz, Chleb miłości, „Tęcza” 1928, nr 5, s. 2.

${ }^{71}$ J. Kisielewski, Przeglad kulturalny, „Tęcza” 1936, nr 11, s. 79.

72 J. Koller, Przegląd wydawniczy, „Tęcza” 1937, nr 11, s. 80-81.

73 Z. Serafinowicz, „Na granicy waskiej jak westchnienie...”. O wierszach Wojciecha Bąka, „Verbum" 1936, nr 1, s. 114-122.

${ }^{74}$ J. Janowski, Karpiński - Bąk - Piechal, „Kultura” 1936, nr 12, s. 5.

${ }^{75}$ E. Misiołek, Poetycki bilans estetyzmu Czesława Miłosza, „Verbum” 1937, nr 3, s. 578-587.

${ }^{76}$ W. Gniazdowski, Tajemnica autorstwa, „Kultura” 1937, nr 5 s. 2.

77 S. Wasylewski, Tom dwudziesty siódmy, „Tęcza” 1929, nr 22 s. 2-4.

${ }^{78}$ J. Drobnik, O nieobojętnej książce, „Tęcza” 1931, nr 28, s. 1-2.

79 E. J. Jankowski, Pani Eliza pisze listy, „Kultura” 1937, nr 17 s. 2. 
Apostoł młodzieży (Poznań 1936) ${ }^{80}$. Z hagiografii na łamach „Verbum” doceniono pracę Marii Cecylii Łubieńskiej Święta Aniela Merici i jej dzieło za uwzględnienie wymagań ówczesnej krytyki historycznej ${ }^{81}$, natomiast w „Tęczy” - książkę o Joannie d’Arc Zofii Zawiszanki pt. Córka Boga ${ }^{82}$. W zawartości wybranych periodyków polecano jednocześnie książki dla młodzieży. Jako przykład mogą posłużyć Czeluskin Czesława Centkiewicza, Szukajcie przyjaciół Zofii Kossak ${ }^{83}$ czy Awantura o Basię i Wielka brama Kornela Makuszyńskiego ${ }^{84}$.

Repertuar wydawniczy proponowany przez redakcje pism był dość szeroki i interesujący. Nie ograniczano się jedynie do literatury religijnej czy też do jednej grupy czytelników pod względem wiekowym. Każdy z odbiorców mógł znaleźć odpowiednią dla siebie poradę w doborze lektury.

\section{Inne formy promocji książek}

Temat książki pojawiał się na łamach pism w różnych działach. Przegląd nowości wydawniczych w „Tęczy” obecny był pod nagłówkiem Wśród książek, Wśród nowych powieści, Najnowsze książki, Nowości księgarskie, Przeglad wydawniczy, O książce w kilku słowach oraz w Kronice wydarzeń kulturalnych. Drukowanie spisów przypadkowo dobranych książek było również tradycją redakcji; ukazywały się one zazwyczaj pod hasłem Książki nadesłane. Już w pierwszym numerze tygodnika zaproponowano czytelnikom kilka książek, które przybliżono krótkimi opisami. Za bardzo pożyteczną pozycję uznano świeżo wydany Przewodnik po literaturze religijnej i pokrewnych dziedzinach filozofii i nauk społecznych pod redakcją o. Jacka Woronieckiego. Układ obszernego przewodnika określono jako przejrzysty, a opracowanie "powierzone profesorom wszechnicy lubelskiej” miało gwarantować sumienny dobór literatury. Szeroko polecano też przetłumaczone na język polski powieści Jamesa Oliviera Curwooda przeznaczone dla młodzieży. Z notki dowiadujemy się, że utwory pisarza w 1927 roku były mało znane, a przetłumaczono jedynie jeden zatytułowany Władca skalnej doliny. Pod hasłem $Z$ literatury francuskiej wspomniano o nowym typie powieści

\footnotetext{
${ }^{80}$ I. Gombrowicz, Recenzje, sprawozdania, omówienia, przeglądy, „Verbum” 1936, nr 2, s. 281-286.

81 Z. Starowieyska-Morstinowa, Recenzje, sprawozdania, omówienia, przeglady, „Verbum” 1935, nr 3, s. 500-505.

82 A. Schroeder, Piękna książka o Joannie D’Arc, „Tęcza” 1930, nr 47, s. 4.

${ }^{83}$ A. Jesionowski, Kilka nowych książek dla młodzieży, „Kultura” 1936, nr 18, s. 3.

${ }^{84}$ Tenże, Apostołowie dobroci, „Kultura” 1937, nr 7, s. 2; tenże, Nowe książki dla młodzieży, „Kultura” 1936, nr 5, s. 7.
} 
mistycznej, do której zaliczono Pod słońcem szatana Georgesa Bernanosa ${ }^{85}$. W celu zachęcenia odbiorców do stałej prenumeraty „Tęczy” od 1932 roku rozpoczęto „Premium Tęczowe”, w ramach którego oferowano pozycje książkowe dla różnych grup czytelników po niższych cenach ${ }^{86}$. Na łamach „Tęczy” organizowano też konkursy z nagrodami książkowymi.

Niekiedy prowadzono zaś rozważania na różne tematy na podstawie książek. Przykładowo w „Verbum” Zofia Abramowiczowa zreferowała poglądy profesora uniwersytetów wrocławskiego i berlińskiego Romano Guardiniego na rolę liturgii w życiu człowieka na bazie dwóch jego książek: Liturgische Bildung (Burg Rothenfels am Main 1923) i Vom Geist der Liturgie (Freiburg $1934)^{87}$. Czasami artykuł w czasopiśmie stanowiła po prostu przedmowa do polskiego przekładu książki, jak to było w przypadku tłumaczenia Trzech reformatorów (Warszawa 1938) Maritaina. Tłumaczem oraz autorem wstępu był ks. Konstanty Michalski ${ }^{88}$.

Pozostałe z periodyków zamieszczały Książki nadesłane i notatki przy okazji wystaw, spotkań kulturalnych i innych imprez dotyczących książek ${ }^{89}$.

\section{Podsumowanie}

Uwzględnione pisma w swoim programie społeczno-kulturalnym opierały się na wartościach i tradycji Kościoła, dlatego też książki promowane na łamach czasopism katolickich były dobierane zgodnie z profilem. Formy promocji były różne. Wśród nich dominowały reklamy i recenzje. W każdym periodyku redakcje zamieszczały też spisy nadesłanych książek. Oferta była dość bogata i różnorodna zarówno pod względem wydawniczym, jak i tematycznym. Uwzględniano bowiem nie tylko tzw. książkę religijną, lecz w dużej mierze także nowo wydane powieści, tomiki poezji, książki historyczne, naukowe i inne. Książka miała swoje stałe miejsce na łamach wszystkich omawianych czasopism i odegrała ważną rolę w ogólnym szerzeniu kultury. Model kulturowy promowany przez redakcje katolickich czasopism zasługuje na uwagę w kontekście ówczesnych warunków społecznych i politycznych. Miał on bowiem oryginalny charakter i własny światopogląd, którego nie dało się pogodzić z ideologią komunistyczną.

\footnotetext{
85 Wśród książek, „Tęcza” 1927, nr 1, s. 15.

${ }^{86}$ Np. „Tęcza” 1932, nr 11, s. 1.

87 Z. Abramowiczowa, Opus Dei. Liturgia w ujęciu R. Guardiniego, „Verbum” 1937, nr 2, s. $266-276$.

${ }^{88}$ K. Michalski, Jacques Maritain, „Verbum” 1937, nr 3, s. 499-511.

89 Szerzej zob.: E. Kristanova, Książka na łamach..., s. 461-465, s. 487-491.
} 
Stąd dzieje niektórych środowisk powojennych, jak „Tygodnika Warszawskiego" zakończyły się tragicznie.

\section{Formy promocji książki w katolickich czasopismach społeczno-kulturalnych 1. połowy XX wieku w Polsce}

Związki zachodzące między książką a prasą należą do istotnych zjawisk kulturalnych. Ich szczególny dynamizm zaznaczył się w XIX i w pierwszej połowie XX w. Książka promowana była przede wszystkim na łamach czasopism społeczno-kulturalnych, których powstanie Andrzej Paczkowski datuje na lata trzydzieste XX w. Wśród nich osobną grupę tworzą pisma katolickie wydawane w okresie II Rzeczypospolitej oraz w pierwszych latach po II wojnie światowej. W artykule uwzględniono najbardziej reprezentatywne tytuły prasowe dla tych dwóch okresów: „Kulturę" (1936-1939), „Tęczę” (1927-1939), „Verbum” (1927-1939), „Tygodnik Powszechny” (1945-1953), „Tygodnik Warszawski” (1945-1948), „Głos Katolicki” (1945-1948). Najczęściej stosowaną formą zachęty do lektury książek w zawartości powyższych pism była reklama wydawnicza i księgarska. Po niej należy wymienić recenzje książek, informacje o nowościach wydawniczych (przeglądy piśmiennictwa i książki nadesłane do redakcji), notatki o imprezach związanych z książką, ogólne rozważania o książkach i czytelnictwie.

\section{Abstract \\ Forms of book promotion in social-cultural catholic periodicals in the first half of $20^{\text {th }}$ century in Poland}

Book and press relationship is important element of cultural phenomenon. Its particular dynamism appeared in $19^{\text {th }}$ and first half of $20^{\text {th }}$ century. Book was promoted mainly in social-cultural periodicals which existed since thirtieth years of $20^{\text {th }}$ century. The catholic papers between 1918 and 1939, 1945 and 1953 were the another group of them. Author wrote in the article about most popular of them like „Kultura” (1936-1939), „Tęcza” (1927-1939), „Verbum” (1927-1939), „Tygodnik Powszechny” (1945-1953), „Tygodnik Warszawski” (1945-1948), „Głos Katolicki” (1945-1948). Frequently form of encouragement to read books were advertisements of publishing companies and book stores. After them were books reviews, information of the latest publications, notes of book events, articles about books and reading. 